\title{
A Transformerless Hybrid Filter Using a Three-Level Diode-Clamped PWM Converter
}

\author{
Takaaki Hatada Student Member (Tokyo Institute of Technology) \\ Hirofumi Akagi Senior Member (Tokyo Institute of Technology)
}

Keywords: active filters, diode rectifiers, hybrid filters, passive filters, three-level converters

This paper deals with a transformerless hybrid active filter integrated into a medium-voltage three-phase diode rectifier. An inverter-driven motor for energy savings in medium-voltage applications requires neither fast speed response nor regenerative braking. As a result, a three-Phase diode rectifier can be used as the front-end converter of the motor drive system, instead of a threephase PWM rectifier. The diode rectifier is much more efficient and reliable as well as less expensive than the PWM rectifier. However, the diode rectifier produces a large amount of harmonic currents, and therefore it does not comply with the harmonic guidelines.

The authors have proposed a transformerless hybrid active filter for harmonic-current compensation of a three-phase diode rectifier with a capacitive load. This hybrid filter is formed by a three-phase passive filter tuned to 7th-harmonic frequency and a small rated active filter based on a three-phase two-level PWM converter. They are directly connected in series without transformer.

This paper addresses a hybrid active filter that is prominent in using a three-level diode-clamped PWM converter. This is well suited to a $6.6-\mathrm{kV}$ transformerless motor drive using a three-phase diode rectifier as the front end. The hybrid filter is characterized by the use of $1.2-\mathrm{kV}$ IGBTs that are currently available from the market at reasonable cost. A concern resulting from introdcuting the threelevel converter to the active filter is voltage imbalance of two split dc capacitors.

Fig. 1 shows a circuit configuration of a 400-V, 15-kW downscaled system that was designed, constructed and tested to confirm

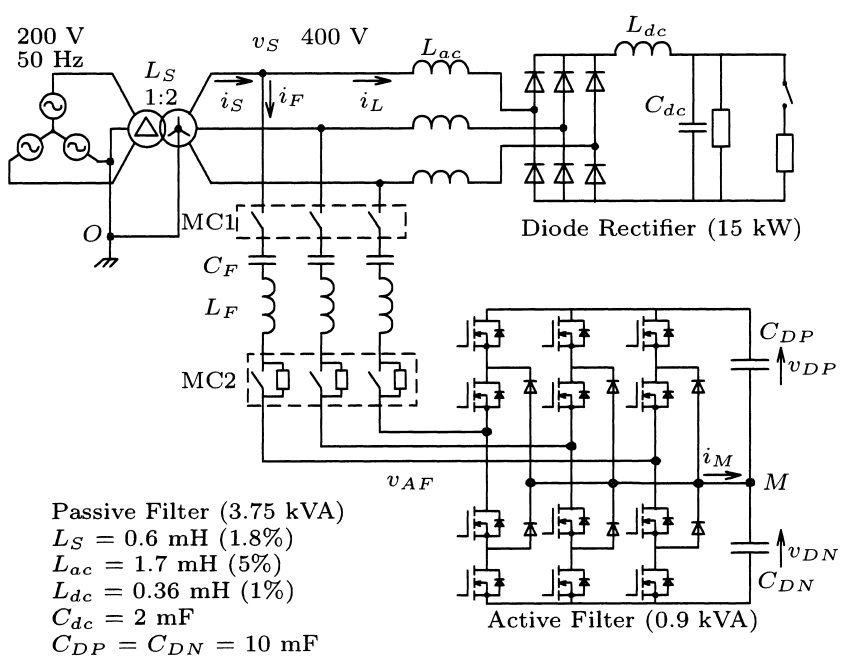

Fig. 1. The 400-V, 15-kW downscaled experimental system the validity of the $6.6-\mathrm{kV}, 1-\mathrm{MW}$ transformerless motor drive system. This paper describes voltage-balancing control for the threelevel converter with focus on its operating principle and experimental verification. The voltage-balancing control introduced to this paper is based on superimposing a 6th-harmonic voltage on the voltage reference of the active filter.

Fig. 2 shows experimental waveforms when the diode rectifier had a dc load rated at $15 \mathrm{~kW}$. Each harmonic currrent contained in $i_{S}$ was below $2 \%$. The THD (total harmonic distortion) of $i_{S}$ was as low as $4.5 \%$, whereas that of $i_{L}$ was as high as $32 \%$. The two dc-capacitor voltages $v_{D P}$ and $v_{D N}$ were well balanced. Experimental results show that the current THD (total harmonic distortion) gets less than $5 \%$, and the voltage-balancing control properly works even in the case of the presence of an intentional disturbance in one of the two dc capacitors connected in series.

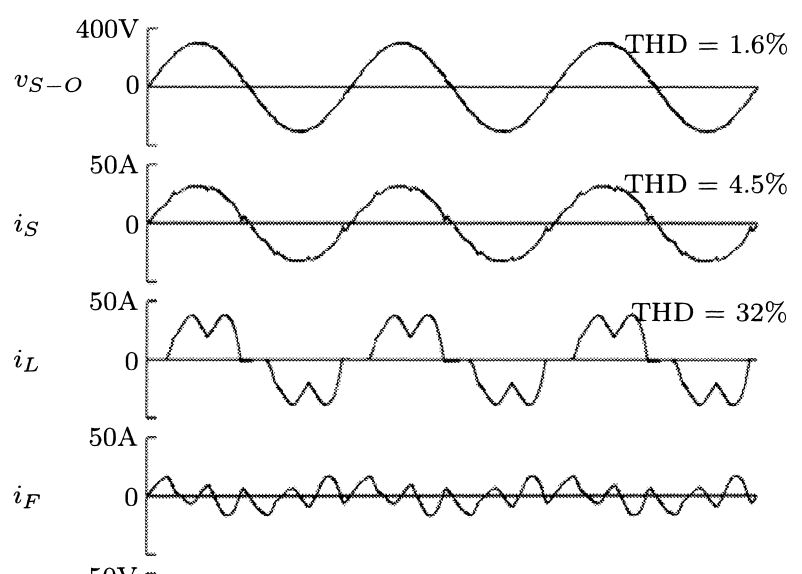

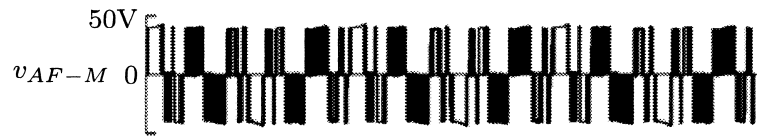
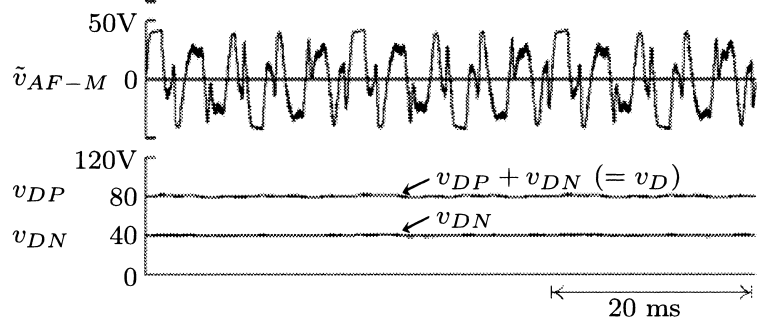

Fig. 2. Experimental waveforms when the hybrid filter was connected to the diode rectifier with the $15-\mathrm{kW}$ dc load, $K=2.0$ p.u. and $V_{D}=80 \mathrm{~V}$ 


\section{3 レベルダイオードクランプPWMコンバータを採用した トランスレス・ハイブリッドフィルタ}

学生員 畑田 高明* 上級会員 赤木 泰文*

\section{A Transformerless Hybrid Filter Using a Three-Level Diode-Clamped PWM Converter}

Takaaki Hatada*, Student Member, Hirofumi Akagi*, Senior Member

This paper deals with a transformerless hybrid active filter integrated into a medium-voltage three-phase diode rectifier used as the front end of an adjustable-speed motor drive. The hybrid filter is formed by a single LC filter tuned to the 7th-harmonic frequency per phase and a small-rated active filter based on a three-phase three-level diode-clamped PWM converter. A three-phase downscaled system rated at $400 \mathrm{~V}$ and $15 \mathrm{~kW}$ is designed, constructed, and tested to verify the filtering performance of the hybrid filter. Experimental results show that the current THD (total harmonic distortion) gets less than $5 \%$, and that the voltage-balancing control proposed in this paper works properly even in transient states.

キーワード：アクティブフィルタ，ダイオード整流回路，ハイブリッドフィルタ，パッシブフィルタ， 3 レベルコンバータ

Keywords: active filters, diode rectifiers, hybrid filters, passive filters, three-level converters

\section{1. まえがき}

近年のパワーエレクトロニクス技術の発展に伴い, PWM インバータによるモータドライブは, 一般産業や交通など 幅広く使用されている。ダイオード整流回路は PWM 整流 回路よりも高効率・高信頼かつ安価であり, 高速応答や電 力回生を必要としない用途（例えば工場・ビルのファン・ ブロアや空調設備など）には直流電源としてダイオード整 流回路を使用できる。その一方で，ダイオード整流回路が 発生する電源高調波電流を抑制する必要がある(1)(2)。

筆者らは先に 7 次同調フィルタ (パッシブフィルタ) と 2 レベル PWM コンバータ（アクティブフィルタ）を直結 したトランスレス・ハイブリッドフィルタを提案し, ダイ オード整流回路が発生する電源高調波電流を良好に抑制で

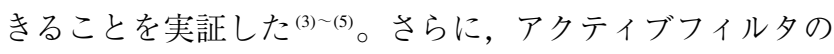
直流電圧は電源線間電圧実効值の $20 \%$ に低減できることを 示した。そこで, このトランスレス・ハイブリッドフィルタ を $6.6 \mathrm{kV}$ モータドライブに併設する場合, アクティブフィ ルタに 3 レベル PWM コンバータ (6) を採用すれば直流電圧 は $1,320 \mathrm{~V}(=6,600 \times 0.2)$ となり, 流通量が多くコスト

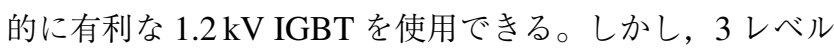

\footnotetext{
* 東京工業大学 大学院理工学研究科電気電子工学専攻

干 152-8552 東京都目黒区大岡山 2-12-1，S3-17

Department of Electrical and Electronic Engineering,

Tokyo Institute of Technology

S3-17, 2-12-1, Ookayama, Meguro-ku, Tokyo 152-8552
}

PWM コンバータの直流中性点は二台の直流コンデンサの 分圧点であるので, 直流コンデンサ電圧に不均一が発生す る可能性がある。文献 (7) では, 正弦波電圧・電流を出力 するモータドライブ用 3 レベル PWM インバータを対象と して, 6 次零相電圧を電圧指令值に重畳する中性点電位制 御を提案している。

本論文では, 文献 (7) の中性点電位制御を非正弦波電圧・ 電流を出力するトランスレス・ハイブリッドフィルタに応 用し, その動作原理を詳細に論じる。さらに, $400 \mathrm{~V} 15 \mathrm{~kW}$ 実験システムを設計・製作し, 中性点電位制御の有効性を 実証する。

\section{2. 実験システム}

〈2・1〉 システム構成Ｆig. 1 にハイブリッドフィルタ

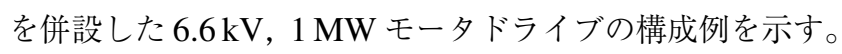
ハイブリッドフィルタは $250 \mathrm{kVA}$ の 7 次同調パッシブフィ ルタと, $60 \mathrm{kVA}$ の 3 レベル PWM コンバータを採用した アクティブフィルタで構成されている。Fig. 1 の留意点は, モータドライブ用 3 レベル PWM インバータの各 IGBT は $4.5 \mathrm{kV}$ IGBT の 2 直列（または $3.3 \mathrm{kV}$ IGBT の 3 直列）を 必要とするが, アクティブフィルタの各IGBTには単一の $1.2 \mathrm{kV} \mathrm{IGBT}$ を使用できる。これはアクティブフィルタの 直流電圧が $1.32 \mathrm{kV}$ (電源電圧 $6.6 \mathrm{kV}$ の $20 \%$ ) であるので, 各直流コンデンサの印加電圧は $660 \mathrm{~V}$ となるためである。 なお, 図中の $L_{S}$ は共通接続点 (PCC : Point of Common Coupling) からみた上位系統の等価インダクタンスであり, 


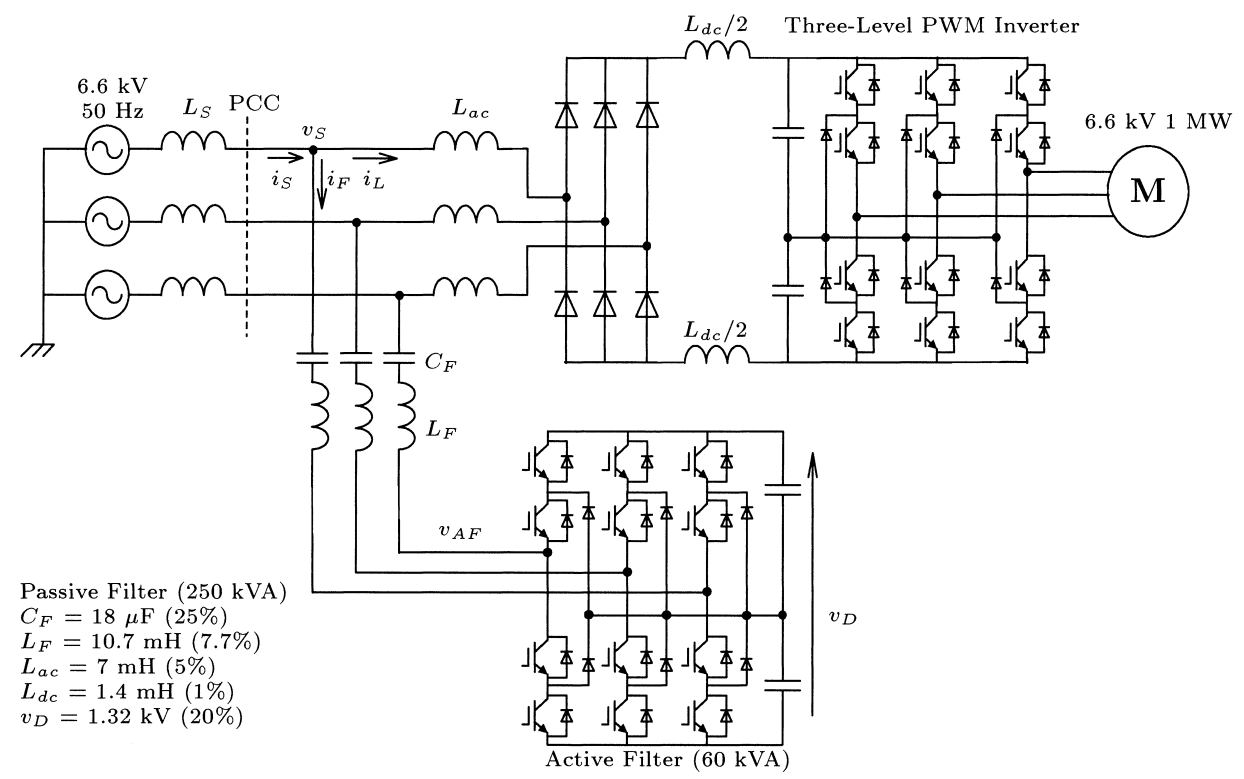

Fig. 1. The 6.6-kV, 1-MW transformerless motor drive equipped with the hybrid filter

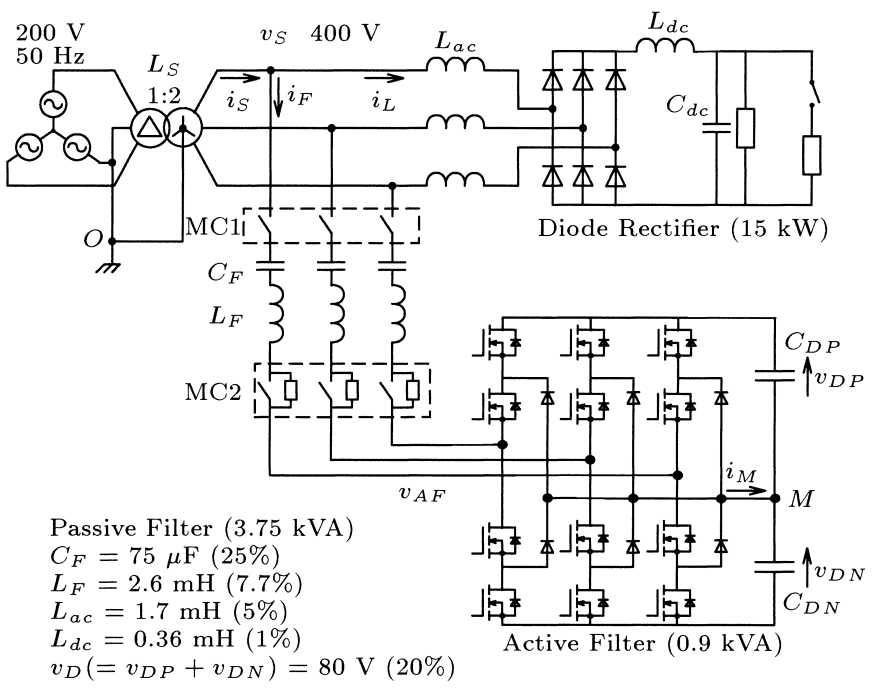

Fig. 2. The 400-V, $15-\mathrm{kW}$ downscaled experimental system

ハイブリッドフィルタのための外付けリアクトルではない。 単独のパッシブフィルタ (5 次, 7 次同調フィル夕，ハイパ スフィルタ）には 4〜8\%の限流リアクトル (8)(9) を外付けす るのが一般的である。

Fig. 2 に $400 \mathrm{~V}, 15 \mathrm{~kW}$ の実験システムを示す。これは Fig. 1 のミニモデルである。Table 1 に Fig. 2 のシステムの 定数を示す。ハイブリッドフィル夕は $400 \mathrm{~V}$ システムに直 接接続されており，アクティブフィルタの主回路は 12 個の $100 \mathrm{~V}$ MOSFET と，6 個のクランプダイオードを使用した 3 レベル PWM コンバータである。ダイオード整流回路の 交流リアクトル $L_{a c}$ は故障電流を抑制し, かつ電源高調波電 流を低減する。Fig. 2 では $L_{a c}$ を $5 \%$ とした。 $L_{S} \quad(=1.8 \%)$ はハイブリッドフィルタの設置点からみた昇圧トランスの 漏れインダクタンスも含む電源インダクタンスである。ア
Table 1. Specifications and Parameters of the 400-V, 15-kW Experimental System

\begin{tabular}{l|c}
\hline Diode rectifier rating & $15 \mathrm{~kW}$ \\
\hline Nominal line-to-line rms voltage & $400 \mathrm{~V}$ \\
\hline Line frequency & $50 \mathrm{~Hz}$ \\
\hline Background system inductance: $L_{S}$ & $0.6 \mathrm{mH}(1.8 \%)$ \\
\hline AC inductor: $L_{a c}$ & $1.7 \mathrm{mH}(5 \%)$ \\
\hline DC inductor: $L_{d c}$ & $0.36 \mathrm{mH}(1 \%)$ \\
\hline DC capacitor of the rectifier: $C_{d c}$ & $2 \mathrm{mF}$ \\
\hline Unit capacitance constant of $C_{d c}: H_{D R}$ & $18.8 \mathrm{~ms}$ \\
\hline Filter capacitor: $C_{F}$ & $75 \mu \mathrm{F}(25 \%)$ \\
\hline Filter inductor: $L_{F}$ & $2.6 \mathrm{mH} \mathrm{(7.7 \% )}$ \\
\hline Resonant frequency between $C_{F}$ and $L_{F}$ & $360 \mathrm{~Hz}$ \\
\hline Quality factor of $L_{F}: Q$ & 25 \\
\hline Active filter rating & $0.9 \mathrm{kVA}$ \\
\hline DC capacitor of the active filter: $C_{D P}=C_{D N}$ & $10 \mathrm{mF}$ \\
\hline DC voltage of the active filter: $V_{D}$ & $80 \mathrm{~V}$ \\
\hline Unit capacitance constant: $H_{H F}$ & $1.1 \mathrm{~ms}$ \\
\hline Cut-off frequency of HPF: $f_{H P F}$ & $50 \mathrm{~Hz}$ \\
\hline Cut-off frequency of LPF: $f_{L P F}$ & $16 \mathrm{~Hz}$ \\
\hline Feedback gain: $K$ & $21 \Omega(200 \%)$ \\
\hline
\end{tabular}

on a three-phase, 400-V, 50-Hz, 15-kVA base

クティブフィルタの直流電圧は電源電圧 $(400 \mathrm{~V})$ の $20 \%$ の $80 \mathrm{~V}$ である。

〈2·2〉 制御システムＦig. 3 にハイブリッドフィルタ の制御回路を示す。制御回路はフィードバック制御, フィー ドフォワード制御，直流コンデンサ電圧制御と中性点電位 制御で構成されている。フィードフォワード制御ブロック の $\left[Z_{F}\right]$ は，パッシブフィルタの回路定数を用いたインピー ダンス行列 (2 行 2 列) であり, 文献 (3) の (12) 式である。

フィードバック制御のゲインは $21 \Omega(2 \mathrm{pu})$ とし, HPF のカットオフ周波数は $50 \mathrm{~Hz}$ ，フィードフォワード制御の $\mathrm{LPF}$ のカットオフ周波数は $16 \mathrm{~Hz}$ とした。アクティブフィ ルタの直流電圧は外部からの電源を使用することなく一定 


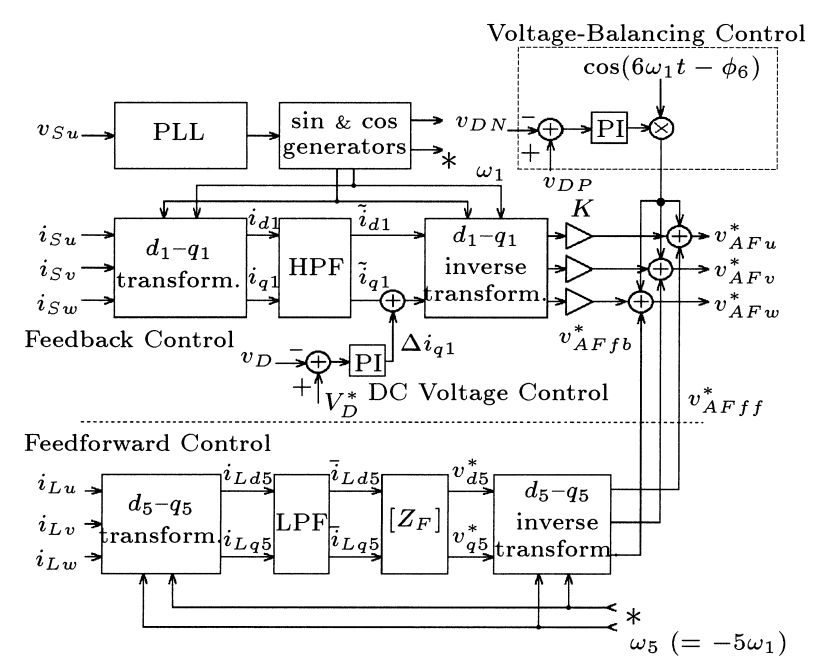

Fig. 3. Control block diagram of the active filter, where $\phi_{6}$ is a constant value of $1.4 \mathrm{rad}$. in the voltage-balancing control

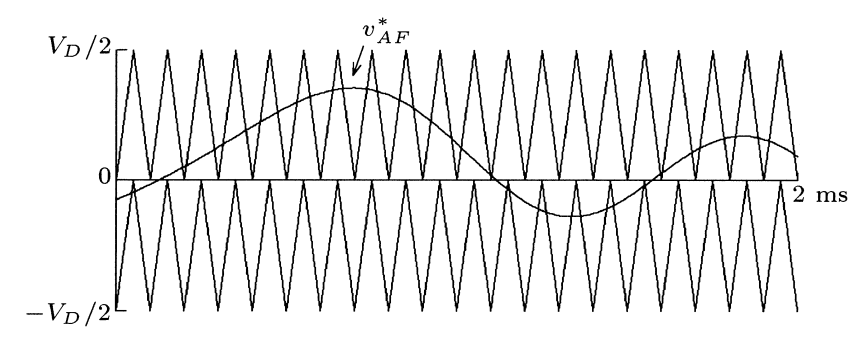

Fig. 4. Two carrier signals and voltage reference $v_{A F}^{*}$ for the active filter

に制御することが可能である。直流コンデンサ電圧制御は $\mathrm{PI}$ 制御を用いており，比例ゲインは $0.56 \mathrm{~A} / \mathrm{V}$ ，積分時間は $20 \mathrm{~ms}$ とし, 直流コンデンサ電圧の指令值 $v_{D}^{*}$ は $80 \mathrm{~V}$ とし た ${ }^{(5)}$ 。中性点電位制御は $\mathrm{P}$ 側のコンデンサ電圧 $v_{D P}$ と $\mathrm{N}$ 側 のコンデンサ電圧 $v_{D N}$ の偏差をとり, PI 制御器を介して 6 次零相電圧を演算し, 交流出力電圧指令值に加算している。 中性点電位制御の比例ゲインは $1 \mathrm{~V} / \mathrm{V}$, 積分時間は $20 \mathrm{~ms}$ とした。

Fig. 4 に 3 レベル PWM コンバータのキャリア波 $(10 \mathrm{kHz})$ と電圧指令值 $v_{A F}^{*}$ を示す。サンプリングはキャリア波の山 と谷で行っているので, サンプリング周期は $50 \mu \mathrm{s}$ である。 Fig. 3 の制御回路は全ディジタル制御を採用し, すべての 演算処理は $50 \mu \mathrm{s}$ 以内に完了している。

\section{3. アクティブフィルタの中性点電位制御}

従来, モータドライブや STATCOM (STATic synchronous COMpensator) のように正弦波電圧・電流を出力する 3 レべ ル PWM インバータの中性点電位制御は国内外で活発に研 究されている(7)(10) (16)。しかし，アクティブフィルタのよう な非正弦波電圧・電流を出力する 3 レベル PWM コンバー 夕の中性点電位制御の研究は少なく ${ }^{(17)(18)}$, しかもその有効 性を実験・検証した論文は筆者らの知る限り発表されてい ないように思われる。特に，3レベル PWM コンバータを

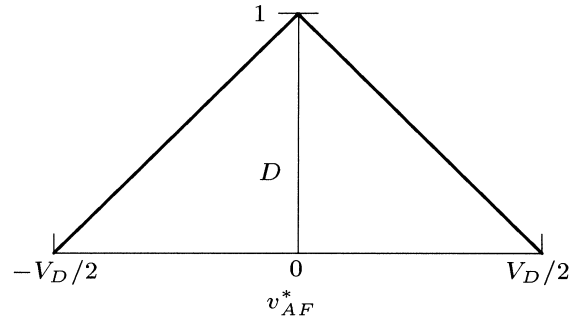

Fig. 5. Voltage reference $v_{A F}^{*}$ and duty factor $D$

トランスレス・ハイブリッドフィルタの主回路に採用した 場合の中性点電位制御を検討した論文は発表されていない。

$\langle\mathbf{3} \cdot \mathbf{1}\rangle$ 通電率 $\boldsymbol{D}$ 通電率とはハイブリッドフィル夕 に流入する電流 $i_{F}$ が中性点 $M$ にクランプする時間比を表 したものである ${ }^{(10)}$ 。キャリア周波数が信号波周波数に比べ て十分に高いと仮定すると, 通電率とフィルタ電流の積が 中性点電流 $i_{M}\left(=D \cdot i_{F}\right)$ になる。Fig. 5 に 3 レベル $\mathrm{PWM}$ コンバータの交流電圧指令值 $v_{A F}^{*}$ と通電率 $D$ の関係を示 す。中性点 $M$ の通電率 $D$ は $v_{A F}^{*}$ の関数となる。

$$
D= \begin{cases}1+2 v_{A F}^{*} / V_{D} & \left(-V_{D} / 2 \leq v_{A F}^{*}<0\right) \\ 1-2 v_{A F}^{*} / V_{D} & \left(0 \leq v_{A F}^{*} \leq V_{D} / 2\right)\end{cases}
$$

ただし， $V_{D}$ は $6.6 \mathrm{kV}$ システムでは $1.32 \mathrm{kV}, 400 \mathrm{~V}$ シス テムでは $80 \mathrm{~V}$ となる。

$\langle\mathbf{3} \cdot 2\rangle$ 中性点電位制御がない場合の中性点電流 $\boldsymbol{i}_{\boldsymbol{M}}$ 簡 単化のため, 以下の仮定を導入する。

・フィル夕電流 $i_{F}$ は, 基本波電流 $i_{F 1}=I_{F 1} \cos \left(\omega_{1} t\right)$ の みとする。

・アクティブフィルタの交流出力電圧 $v_{A F}$ は, 主成分で ある 5 次成分 $v_{A F 5}=V_{A F 5} \cos \left(5 \omega_{1} t-\phi_{5}\right)$ のみとする。

Fig. 6 に中性点電位制御を適用しない場合における中性 点電流波形を示す。これらの波形は回路シミュレータを用 いたシミュレーション結果ではなく, 計算ソフト (Excel) による数值計算の結果を作図したものある。ここで留意す べき点は $i_{F 1}$ に対する $v_{A F 5}$ の位相 $\phi_{5}$ の計算である。これ は Fig. 9 の $i_{L}$ の実測波形からフィードバック制御が出力す る 5 次電圧を計算し， $i_{L}$ の実測波形とパッシブフィルタの 回路定数からフィードフォワード制御が出力する 5 次電圧 を計算し，これらを加算して $\phi_{5}$ を演算する。次に Fig. 5 を 用いて $v_{A F 5}$ の瞬時值から通流率 $D$ を求め, $D \cdot i_{F 1}\left(=i_{M}\right)$ を得る。中性点電流 $i_{M}$ の直流成分は零となるので, 理論的 には直流コンデンサ電圧にアンバランスは発生しない。し かし, 実際の装置では回路の不平衡などのため直流コンデ ンサ電圧の不均一が発生する可能性があり, 不均一を抑制 する必要がある。

〈3・3 中性点電位制御の動作原理 中性点電位を制 御するために, アクティブフィルタの電圧指令值 $v_{A F}^{*} に 6$ 次零相電圧を重畳する。Fig. 7 に中性点電位制御がある場 合の各部波形を示す。これらの波形は Fig. 6 と同様に計算 ソフト (Excel) による数值計算の結果を作図したものであ る。Fig. 7 では以下の仮定を導入した。 


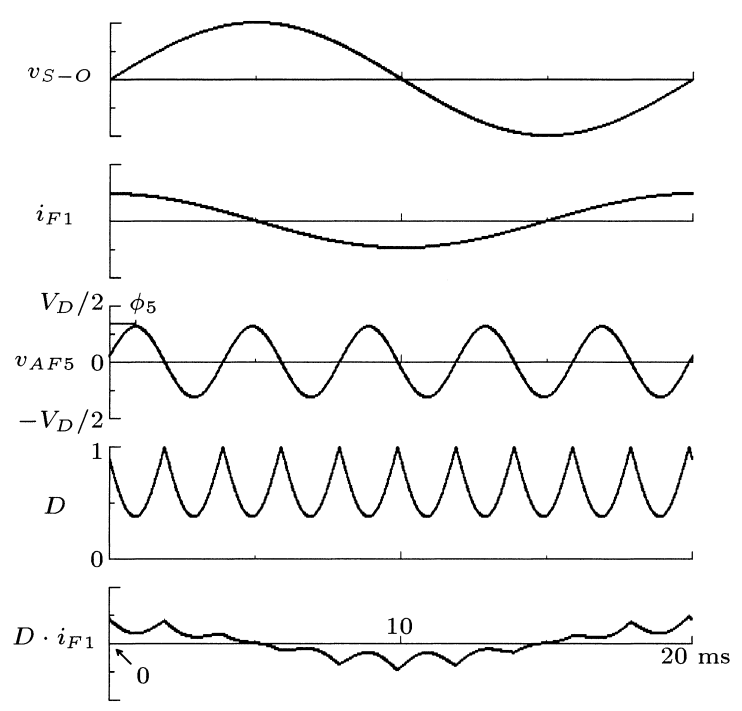

Fig. 6. Waveforms of $v_{A F 5}, i_{M}\left(=D \cdot i_{F 1}\right)$ and others obtained by numerical analysis when no zero-sequence voltage is superimposed on each voltage reference

-フィルタ電流は基本波電流と 5 次高調波電流のみを考 慮し, $i_{F}=I_{F 1} \cos \left(\omega_{1} t\right)+I_{F 5} \cos \left(5 \omega_{1} t-\phi_{5}^{\prime}\right)$ とする。

- 5 次出力電圧は $v_{A F 5}=V_{A F 5} \cos \left(5 \omega_{1} t-\phi_{5}\right)$ とする。

(Fig. 6 の $\phi_{5}$ と同一であり, $\phi_{5}=1.40 \mathrm{rad}$ )

- 6 次重畳電圧は $v_{A F 6}=V_{A F 6} \cos \left(6 \omega_{1} t-\phi_{6}\right)$ とする 。 ここで, 5 次電流 $i_{F 5}$ の振幅 $I_{F 5}$ と位相 $\phi_{5}^{\prime}$ は Fig. 9 の $i_{F}$ の 実測波形から求めた。5 次電压 $v_{A F 5}$ と 6 次電圧 $v_{A F 6}$ を加 算して $D$ を計算し, 中性点電流 $i_{M}\left(=D \cdot i_{F 1}+D \cdot i_{F 5}\right)$ を 作図した。Fig. 7 の $D \cdot i_{F 1}$ の直流成分は負となるので，中 性点電流は平均的には流出する。この場合，P側直流コン デンサを充電し， $\mathrm{N}$ 側直流コンデンサを放電することにな り, 中性点電位は下がる。これは中性点電位を制御できる ことを意味している。

次に, 重畳する 6 次成分の位相を検討するために数值解 析を行った。その結果,

$$
\phi_{5}=\phi_{6}
$$

の場合に中性点電流 $i_{M}\left(D \cdot i_{F 1}\right)$ の直流成分が最大となった。 その理由を以下に説明する。初期位相に関係なく $10 \mathrm{~ms}$ 後 に 5 次成分 $v_{A F 5}$ は 2.5 周期だけ進み， 6 次成分 $v_{A F 6}$ は 3 周期だけ進む。つまり Fig. 7 の $\mathrm{t}=0$ で 5 次成分と 6 次成分 が同位相の場合， $10 \mathrm{~ms}$ 後には位相が逆になるので $v_{A F 5}+$ $v_{A F 6}$ の振幅は小さくなる。その結果，中性点にクランプす る時間比率 $D$ が大きくなる。Fig. 7 の $i_{F 1}$ は $10 \mathrm{~ms}$ 付近で 負の最大值となり，しかも通電率 $D$ が大きくなるため，中 性点電流の電源一周期の平均值（直流成分）は負となる。

フィルタ電流 $i_{F}$ の 5 次高調波の振幅 $I_{F 5}$ は基本波振幅 $I_{F 1}$ の 1.25 倍であるが， $D \cdot i_{F 5}$ の直流成分は $D \cdot i_{F 1}$ のそ れと比較して実用的には無視できる理由を以下に説明する。

\footnotetext{
${ }^{\dagger}$ Fig.7 では, 中性点電位制御の動作原理を説明するために $V_{A F 6} / V_{A F 5}=0.6$ として作図したが, 実験波形の $V_{A F 6} / V_{A F 5}$ は 0.02 程度である。
}

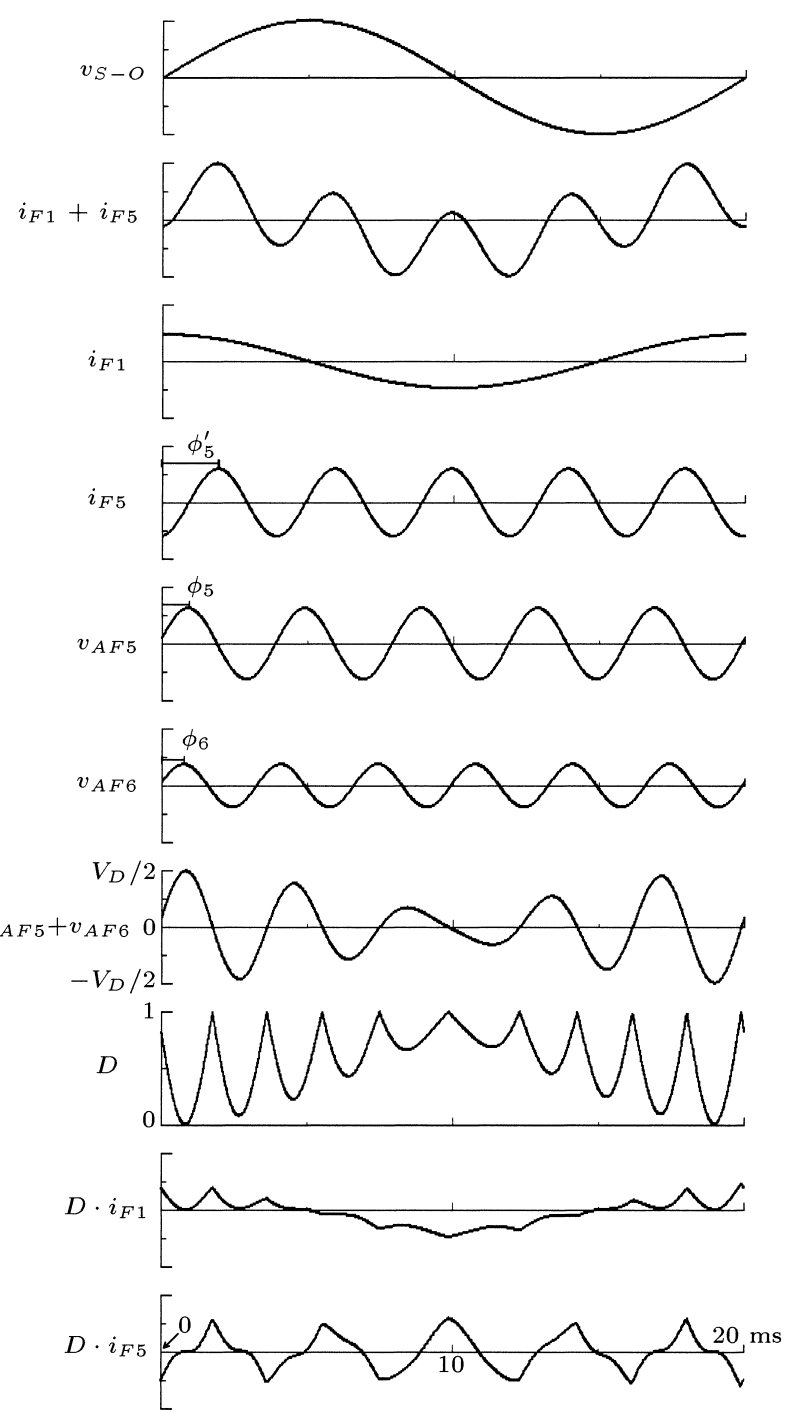

Fig. 7. Waveforms of $v_{A F 5}+v_{A F 6}, D \cdot i_{F 1}, D \cdot i_{F 5}$ and others by numerical analysis when a 6th-harmonic zerosequence voltage for voltage balancing is superimposed on each voltage reference with a relation of $\phi_{5}=\phi_{6}$

Fig. 7 の $D \cdot i_{F 1}$ と $D \cdot i_{F 5}$ を比較すると， $i_{F 1}$ が正の期間と 負の期間とで通電率 $D$ の平均值が大きく異なるため, 中性 点電流の平均值も大きくなる。一方， $i_{F 5}$ の波形と $D$ の波 形に注目すると， $i_{F 5}$ が一周期 $(4 \mathrm{~ms})$ 経過した期間に， $D$ は極大值と極小值の間を 2 回往復する。すなわち, $i_{F 5}$ が 正となる期間での $D$ の平均值と負となる期間での $D$ の平 均值に差はほとんど生じない。つまり，20 ms 経過した時 点での $D \cdot i_{F 5}$ の直流成分は, $D \cdot i_{F 1}$ の直流成分より小さく なる。

$\langle\mathbf{3} \cdot \mathbf{4}\rangle v_{A F}$ と $i_{F}$ の高調波成分が中性点電位制御に与え る影響 以下では， $v_{A F}$ と $i_{F}$ の高調波成分が中性点電位 制御に及ぼす影響について総合的に考察する。

Table 2 に $v_{A F}$ と $i_{F}$ の基本波, 5 次, 7 次, 11 次, 13 次 成分の実測值, 中性点電流 $\left(D \cdot i_{F n}\right)$ の直流成分の計算值を 示す。 $v_{A F}$ については 5 次成分を， $i_{F}$ と中性点電流の直流 成分については基本波を $100 \%$ とした。ここで， $v_{A F}$ と $i_{F}$ 
Table 2. Measured harmonic components of $v_{A F}$ and $i_{F}$ when the rated load of $15 \mathrm{~kW}$ is applied, and calculated dc mean components of $D \cdot i_{F n}(n=1,5,7$, $11,13)$, expressed in [\%], where the voltage-balancing control is enabled with the use of a relation of $v_{A F}=$ $v_{A F 1}+v_{A F 5}+v_{A F 6}+v_{A F 7}+v_{A F 11}+v_{A F 13}$ for calculation of $D$

\begin{tabular}{c|c|c|c|c|c}
\hline Harmonic order: $n$ & 1 st & 5 th & 7 th & 11 th & 13th \\
\hline Harmonic components of $v_{A F}$ & 30 & 100 & 6 & 27 & 30 \\
\hline Harmonic components of $i_{F}$ & 100 & 125 & 31 & 16 & 10 \\
\hline DC components of $D \cdot i_{F n}$ & 100 & 20 & 8 & 4 & 1 \\
\hline
\end{tabular}

の各次成分は Fig. 9 の波形から求めた実測值であり，中性 点電流の直流成分は Fig. 7 と同様の数值解析による計算值 である。中性点電流の直流成分の計算は， $v_{A F}$ に関しては 6 次重畳成分 $\left(V_{A F 6} / V_{A F 5}=0.02\right)$ を含む上記の基本波と 高調波成分を加算した結果から $D$ を算出し, $D \cdot i_{F n}$ を計算

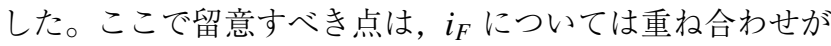
成立するが， $v_{A F}$ については重ね合わせが成立しないこと である。Table 2 より， $i_{F 5}$ が中性点電位制御に与える影響 は $i_{F 1}$ の $20 \%$ であり， $i_{F 7}$ の影響は $i_{F 1}$ の $8 \%, i_{F 11}$ と $i_{F 13}$ の影響は $i_{F 1}$ の $4 \%$ 以下となるので，フィル夕電流 $i_{F}$ の基 本波成分 $i_{F 1}$ 以外の高調波電流による中性点電位制御への 影響は実用的には無視できる。

\section{4. 実験結果}

〈4・1〉 パッシブフィルタを単体で接続した場合Ｆig. 8 にパッシブフィルタ単体を接続した場合の実測波形を示す。 負荷電流 $i_{L}$ の総合歪率 $(\mathrm{THD})$ は $28 \%$ あるが，電源電流 $i_{S}$ の THD は $32 \%$ あり, 系統連系ガイドライン（総合歪 率 5\%以下かつ各次高調波電流 $3 \%$ 以下）を満足しない。さ らに設置点電圧 $v_{S-O}$ の THD は $3.2 \%$ に達している。 $i_{L}$ の 5 次成分 (主要高調波) は $26 \%$ であるか， $i_{S}$ の 5 次成分は $31 \%$ となっいる。この理由は, パッシブフィルタの同調 周波数が 7 次であるので， 7 次よりも低い高調波では，い わゆる「高調波拡大現象」を引き起こすからである。

〈4·2〉 ハイブリッドフィルタを接続した場合Ｆig.9 にハイブリッドフィルタを接続した場合の定格負荷 $(15 \mathrm{~kW})$ かつ定常時の実験波形を示す。アクティブフィルタの交流 出力電圧 $v_{A F-M}$ は直流コンデンサ電圧の中性点 $\mathrm{M}$ から測 定したものであり，波形測定にはWE7000（サンプリング 周波数 $1 \mathrm{MS} / \mathrm{s}$ ）を使用した。 $\tilde{v}_{A F-M}$ は， $v_{A F-M}$ の波形をわ かりやすくするためにカットオフ周波数 $4 \mathrm{kHz}$ の一次ロー パスフィルタを介したものである。

Table 3 に電源電流と負荷電流の高調波成分と THD を示 す。負荷電流 $i_{L}$ は $30 \%$ の 次高調波を含むため, THD は $32 \%$ に達しているが, 電源電流 $i_{S}$ の各次高調波成分は $2 \%$ 以 下になっており，THDは 4.5\%である。この波形は系統連 系ガイドラインを満足している。設置点電圧 $v_{S-O}$ の THD は $1.6 \% に$ 低減されているが，零にはできない。この理由

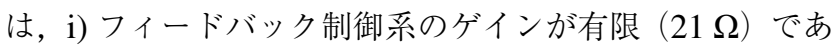

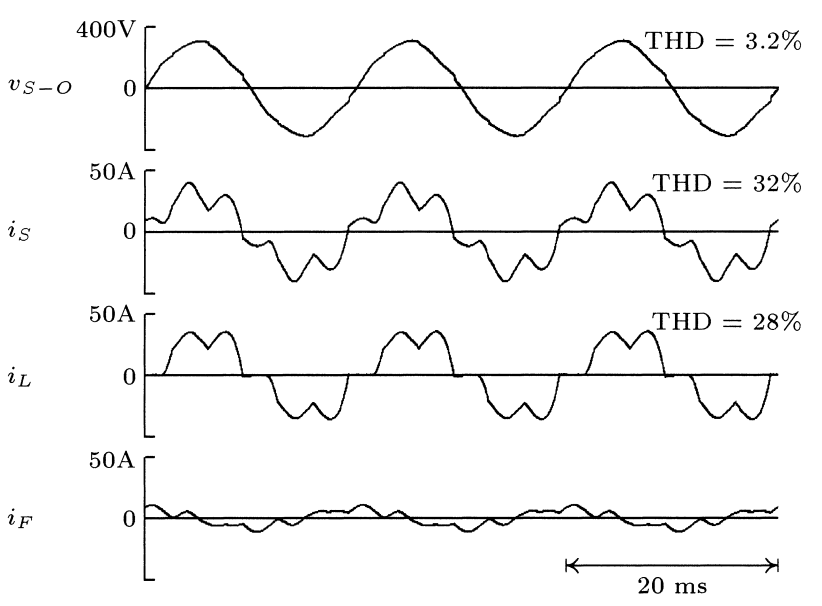

Fig. 8. Experimental waveforms when the stand-alone passive filter was connected to the diode rectifier with the rated dc load of $15 \mathrm{~kW}$

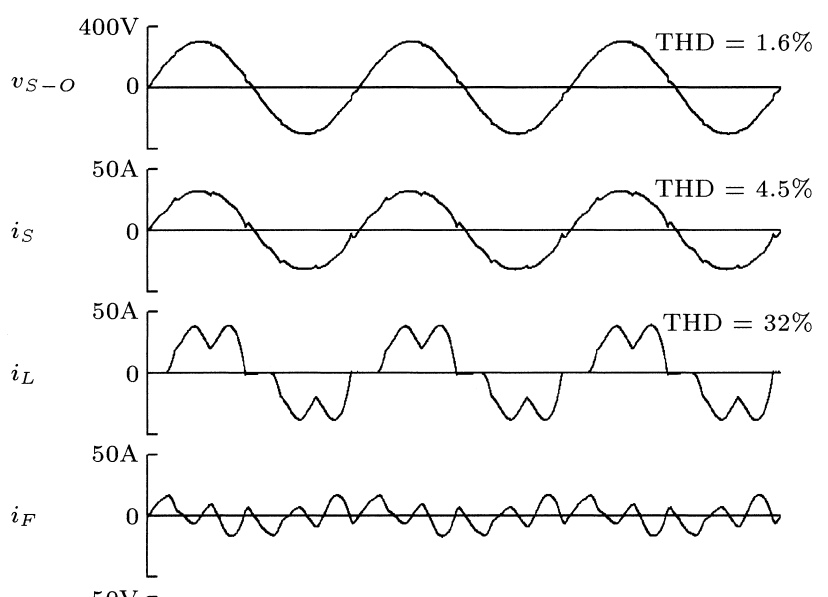
${ }_{v_{A F-M}}{ }^{50 \mathrm{~V}}{ }_{0}$

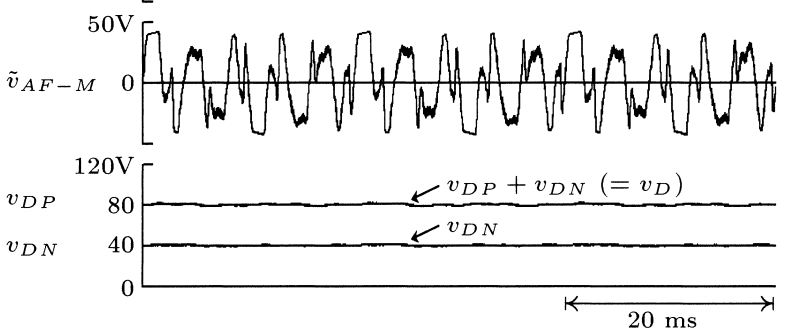

Fig. 9. Experimental waveforms when the hybrid filter was connected to the diode rectifier with the $15-\mathrm{kW} \mathrm{dc}$ load

ること, ii) 実験室の三相電源に高調波電圧を含むためであ る。 $v_{D}$ と $v_{D N}$ の波形から, アクティブフィルタの中性点電 位は良好にバランスしていることがわかる。

Fig. 10 は, Fig. 9 の $v_{A F-M}$ と $\tilde{v}_{A F-M}$ の時間軸を拡大した ものである。この波形から明らかなように， $v_{A F-M}$ は40か ら $0 \mathrm{~V}$ または $0 \mathrm{~V}$ から $-40 \mathrm{~V}$ のスイッチングを行い, $40 \mathrm{~V}$ から $-40 \mathrm{~V}$ のスイッチングは行っていない。これは 3 レベ ル PWM コンバータとして正常に動作していることを意味 している。 
Table 3. Current THD and harmonics obtained from experimental waveforms, expressed as the harmonic-tofundamental current ratio in [\%]

\begin{tabular}{c|c|c|c|c|c|c|c|c|c|c|c|c|c|c}
\hline Hybrid Filter & 3rd & 5 th & 7 th & 11 th & 13th & 17 th & 19th & 23rd & 25th & 29th & 31 st & 35th & 37 th & THD \\
\hline$v_{S-O}(15 \mathrm{~kW})$ & 0.3 & 0.6 & 0.4 & 0.7 & 0.5 & 0.5 & 0.6 & 0.3 & 0.3 & 0.3 & 0.3 & 0.3 & 0.3 & 1.6 \\
\hline$i_{S}(15 \mathrm{~kW})$ & 2.0 & 1.6 & 0.9 & 2.0 & 2.1 & 1.1 & 1.0 & 0.9 & 0.6 & 0.7 & 0.6 & 0.4 & 0.5 & 4.5 \\
\hline$i_{L}(15 \mathrm{~kW})$ & 1.4 & 30.3 & 7.6 & 4.9 & 3.2 & 1.9 & 1.7 & 1.0 & 0.8 & 0.6 & 0.5 & 0.4 & 0.4 & 31.9 \\
\hline \hline Passive Filter & 3 rd & 5 th & 7 th & 11 th & 13 th & 17 th & 19 th & 23 rd & 25 th & 29 th & 31 st & 35 th & 37 th & THD \\
\hline$v_{S-O}(15 \mathrm{~kW})$ & 0.3 & 2.8 & 0.6 & 0.9 & 0.5 & 0.5 & 0.5 & 0.3 & 0.2 & 0.2 & 0.2 & 0.2 & 0.2 & 3.2 \\
\hline$i_{S}(15 \mathrm{~kW})$ & 0.9 & 31.1 & 2.7 & 3.0 & 2.9 & 1.1 & 1.2 & 0.7 & 0.6 & 0.5 & 0.5 & 0.3 & 0.4 & 31.6 \\
\hline$i_{L}(15 \mathrm{~kW})$ & 0.9 & 26.3 & 6.2 & 4.3 & 3.3 & 1.3 & 1.5 & 0.8 & 0.7 & 0.6 & 0.6 & 0.3 & 0.4 & 27.7 \\
\hline
\end{tabular}

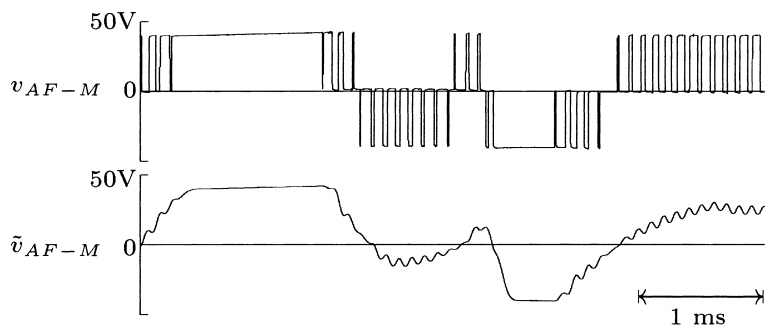

Fig. 10. Time-expanded waveforms of $v_{A F-M}$ and $\tilde{v}_{A F-M}$ in Fig. 9
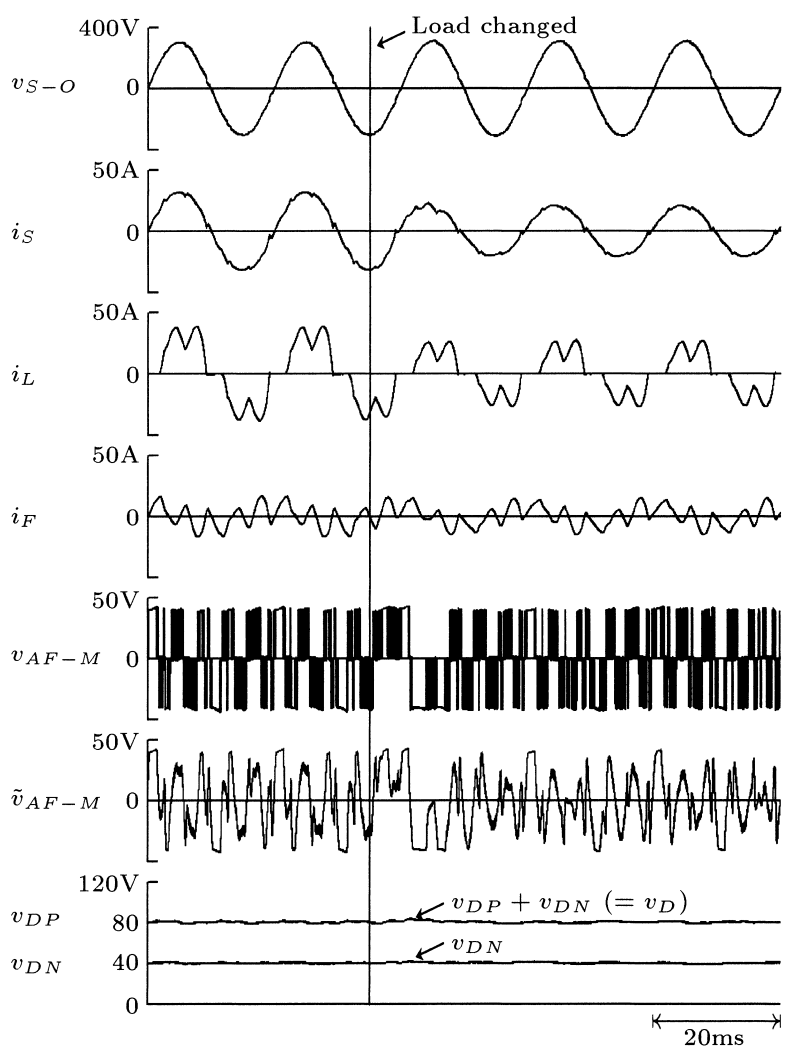

Fig. 11. Experimental waveforms with a step change in a dc load from $15 \mathrm{~kW}$ to $10 \mathrm{~kW}$

$\langle\mathbf{4} \cdot \mathbf{3}\rangle \quad$ 過渡時の実験波形Ｆig. 11 にハイブリッドフィ ルタを接続して直流負荷を $15 \mathrm{~kW}$ から $10 \mathrm{~kW}$ にステップ 状に変化させた場合の実測波形を示す。負荷変動直後の半 周期程度は $i_{S}$ がわずかに歪んでいるが，この程度の短い期 間の歪みが他のシステムに悪影響を及ぼすことはない。ま

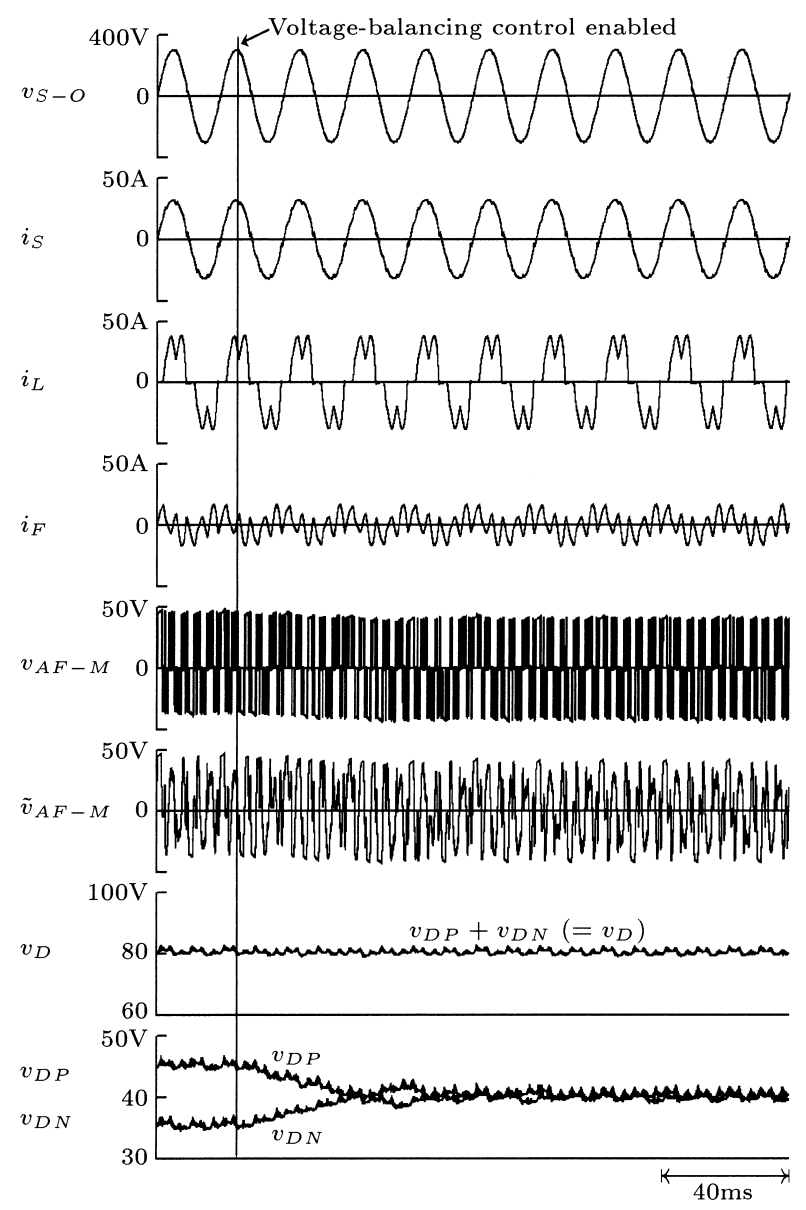

Fig. 12. Experimental waveforms with the rated load of $15 \mathrm{~kW}$ before and after enabling the voltage-balancing control

た, 負荷変動直後アクティブフィルタの直流電圧 $v_{D}$ は $84 \mathrm{~V}$ （80Vの 5\%）まで上昇したが，この電圧上昇がスイッチン グデバイスの耐圧を脅かすことはない。また, 負荷変動後 も良好に高調波電流を補償し, 直流コンデンサ電圧は過渡 時においてもバランスしている。

$\langle\mathbf{4} \cdot 4\rangle$ 中性点電位制御の効果 Fig. 12 は定格運転中 に中性点電位制御を動作させた場合の実測波形である。こ の実験では $\mathrm{N}$ 側直流コンデンサに $250 \Omega$ の抵抗を並列に意 四的に接続している。その結果, $\mathrm{N}$ 側直流コンデンサには新 たな損失 $4.6 \mathrm{~W}\left(=34^{2} / 250\right)$ が発生するが，この損失はア クティブフィルタ容量 $(900 \mathrm{VA})$ の $0.5 \%$ であ。中性点電 
位制御を停止した場合，6V程度 $(=15 \%)$ の電圧不均一が 発生したが，中性点電位制御を動作させると 4 周期 $(80 \mathrm{~ms})$ 後には直流コンデンサ電圧がバランスした。Fig. 12 のバラ ンスした状態での $v_{A F-M}$ に含まれる 6 次成分と 5 次成分の 振幅比は $8 \%(2.4 \mathrm{~V})$ であった。一方， $\mathrm{N}$ 側直流コンデンサ に抵抗を接続しない通常の場合，Fig.9の $v_{A F-M}$ の波形に 含まれる 6 次成分と 5 次成分の振幅比は $2 \%$ あった。こ のように, 6 次重畳電圧は主要高調波電圧 (5 次)に比べて 十分に小さいので，本論文で提案した中性点電位制御がア クティブフィルタの制御特性に与える影響は無視できる。

\section{5. 結 論}

本論文では，トランスレス・ハイブリッドフィルタのア クティブフィルタに 3 レベル PWM コンバータを採用し, 中性点電位制御の動作原理を論じた。さらに, $400 \mathrm{~V} 15 \mathrm{~kW}$ 実験システムを設計・製作し，その効果を実証した。本論

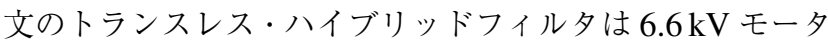

ドライブの電源高調波対策に有効である。

(平成 19 年 3 月 23 日受付，平成 19 年 5 月 14 日再受付)

\section{文献}

(1) H. Akagi: "Active Harmonic Filters", Proceedings of the IEEE, Vol.93, No.12, pp.2128-2141 (2005)

(2) H. Akagi, E. H. Watanabe, and M Aredes: "Instantaneous Power Theory and Applications to Power Conditioning", IEEE Press (2007)

(3) S. Srianthumrong, Y. Tamai, and H. Akagi: "A Proposal of a 3.3-kV/6.6kV Transformerless Hybrid Filter, and Experimental Verification Based on a 200-V Laboratory System", IEEJ Trans., Vol.122-D, No.10, pp.989-998 (2002-10) (in Japanese)

Sunt Srianthumrong ・ 玉井康寛・赤木泰文：「3.3kV/6.6 kV トランスレ ス・ハイブリッドフィルタの提案と $200 \mathrm{~V}$ ミニモデルによる実験的 検討」, 電学論 D, 122, 10, pp.989-998 (2002-10)

(4) Y. Tamai, S. Srianthumrong, and H. Akagi: "Comparisons Between a Hybrid Shunt Active Filter and Pure Active Filter", IEEJ Trans., Vol.124-D, No.5, pp.494-502 (2004-5) (in Japanese)

玉井康寛・Sunt Srianthumrong ・赤木泰文：「ハイブリッドフィル夕 とアクティブフィルタの比較・検討」, 電学論 D, 124, 5, pp.494-502 (2004-5)

(5) W. Tangtheerajaroonwong, T. Hatada, K. Wada, and H. Akagi: "Design and Performance of a Transformerless Shunt Hybrid Filter Integrated into a Three-Phase Diode Rectifier", IEEE Trans. Power Electron., Vol.22, No.5, pp.1882-1889 (2007)

(6) A. Nabae, I. Takahashi, and H. Akagi: "A New Neutral-Point-Clamped PWM Inverter”, IEEE Trans. IA, Vol.17, No.5, pp.518-523 (1981)

（7）神谷茂・鈴木 究・大沢 博・橋井眞：「3 レベルインバータ中 性点電流の直流分の解析と中性点電位の変動抑制制御」, 平 5 電学全 大, 516 (1993)

（8）山崎裕和・室谷金義・大西一彦：「電力系統の高調波と交流フィル 夕」, 日新電機技報, Vol.20, No.1, pp.60-75 (1975)

（9）今井孝二 監修:「パワーエレクトロニクスハンドブック」, $K \& D$ プ ランニング, pp.594-601 (2002)

(10) S. Ogasawara, T. Sawada, and H. Aakagi: "Analysis of the Neutral Point Po- tential Variation of Neutral-Point-Clamped Voltage Source PWM Inverters", IEEJ Trans., Vol.113-D, No.1, pp.41-48 (1993-1) (in Japanese) 小笠原悟司・沢田 直・赤木泰文:「中性点クランプ電圧形 PWM イン バー夕の中性点電位変動の解析」, 電学論 D, 113, 1, pp.41-48 (1993-1)

(11) M. Matsui: "Static Var Compensator Using Neutral-Point-Clamped PWM Inverter and its Control Scheme", Conf. Rec. 1995 IPEC-Yokohama, pp.488-493 (1995)

12) M. Ichihara, T. Akiyama, J. Shimomura, K. Tamura, and M. Terashima: "Control Method of the Neutral Point Voltage of NPC Inverter Connected to Utility Lines", Conf. Rec. IEEJ-IAS, 261, pp.197-200 (1997) (in Japanese) 市原昌文・秋山岳夫・下村潤一・田村公良・寺嶋正之：「系統連系中 性点クランプ形インバータの中性点電位制御」, 平 7 電学産業応用部 門全大, 261,pp.197-200 (1997)

(13) N. Celanovic and D. Boroyevich: "A Comprehensive Study of Neutral-Point Voltage Balancing Problem in Three-Level Neutral-Point-Clamped Voltage Source PWM Inverters", IEEE Trans. Power Electron., Vol.15, No.2, pp.242-249 (2000)

14） H.D.T. Mouton: "Natural Balancing of Three-Level Neutral-Point-Clamped PWM Inverters", IEEE Trans. Ind. Appl., Vol.49, No.5, pp.1017-1024 (2002)

15) B.P. McGrath, D.G. Holmes, and T.A. Lipo: "Optimised Space Vector Switching Sequences for Mutilevel Inverters", IEEE Trans. Power Electron., Vol.18, No.6, pp.1293-1301 (2003)

(16) B.P. McGrath and D.G. Holmes: "Multicarrier PWM Strategies for Multilevel Inverters", IEEE Trans. IE, Vol.49, No.4, pp.858-867 (2005)

17) V. Aburto, M. Schenider, L. Moran, and J. Dixon: "An Active Power Filter Implemented with a Three-Level NPC Voltage Source Inverter", Conf. Rec. IEEE-PESC, pp.1121-1126 (1997)

(18) T. Jin, J. Wen, and K. Smedley: "Control and Topologies for Three-Phase Three-Level Active Power Filters", Conf. Rec. IEEE-APEC, pp.655-664 (2005)

畑 田 高 明 (学生員) 1982 年 4 月 20 日生。 2005 年 3 月東 京都立大学工学部電気工学科卒業。2007 年 3 月 東京工業大学大学院理工学研究科電気電子工学専 攻修士課程修了。同年 4 月東洋電機製造（株）入 社，現在に至る。在学中は電力用アクティブフィ ル夕に関する研究に従事。

赤 木 泰 文（上級会員） 1951 年 8 月 19 日生。1979 年 3 月

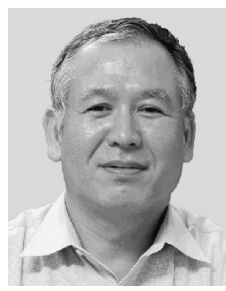
東京工業大学大学院博士課程電気工学専攻修了, 工学博士。長岡技術科学大学助手 · 助教授, 岡山 大学教授を経て，2000 年 1 月東京工業大学教授。 パワーエレクトロニクスの研究に従事。電気学 会学術振興賞・論文賞を 4 回, IEEE Transactions Prize Paper Award を 4 回受賞。1996 年 IEEE Fellow。1998 年 IEEE Distinguished Lecturer。2001 年 IEEE William E. Newell Power Electronics Award。2004 年 IEEE Industry Applications Society Outstanding Achievement Award。2006 年文 部科学大臣表彰科学技術賞 (研究部門)。2007 年 IEEE Power Electronics Society President。 